\title{
Accounting als technologie: enige beschouwingen bij de economische rol van berichtgeving
}

Citation for published version (APA):

Buijink, W. F. J. (1994). Accounting als technologie: enige beschouwingen bij de economische rol van berichtgeving. Maastricht University. https://doi.org/10.26481/spe.19940603wb

Document status and date:

Published: 03/06/1994

DOI:

10.26481/spe.19940603wb

Document Version:

Publisher's PDF, also known as Version of record

\section{Please check the document version of this publication:}

- A submitted manuscript is the version of the article upon submission and before peer-review. There can be important differences between the submitted version and the official published version of record.

People interested in the research are advised to contact the author for the final version of the publication, or visit the DOI to the publisher's website.

- The final author version and the galley proof are versions of the publication after peer review.

- The final published version features the final layout of the paper including the volume, issue and page numbers.

Link to publication

\footnotetext{
General rights rights.

- You may freely distribute the URL identifying the publication in the public portal. please follow below link for the End User Agreement:

www.umlib.nl/taverne-license

Take down policy

If you believe that this document breaches copyright please contact us at:

repository@maastrichtuniversity.nl

providing details and we will investigate your claim.
}

Copyright and moral rights for the publications made accessible in the public portal are retained by the authors and/or other copyright owners and it is a condition of accessing publications that users recognise and abide by the legal requirements associated with these

- Users may download and print one copy of any publication from the public portal for the purpose of private study or research.

- You may not further distribute the material or use it for any profit-making activity or commercial gain

If the publication is distributed under the terms of Article $25 \mathrm{fa}$ of the Dutch Copyright Act, indicated by the "Taverne" license above, 


\section{Accounting als technologie: enige beschouwingen bij de economische rol van berichtgeving.}

\section{Rede}

in verkorte vorm uitgesproken bij de aanvaarding van het ambt van hoogleraar in de Bedrijfseconomie, in het bijzonder Berichtgeving, aan de Rijksuniversiteit Limburg op vrijdag 3 juni 1994

door

Dr W.F.J. Buijink 
$P=2,2:$

Universiteitsbibiiotheek

Rijksuniversiteit Lumburg

Aan mijn kinderen, ouders en aan Beatrice. 


\section{Proloog}

\section{Dames en heren,}

Eind maart van dit jaar heb ik mij in een boekwinkel in Antwerpen een boek aangeschaft met de titel 'Complexity' (Waldrop (1992)). Dat boek heb ik in één ruk uitgelezen. Toen ik het in de boekwinkel oppakte om het te bekijken, had ik door de titel de indruk dat het een holistisch getint boek zou zijn over de structuur van het alles, en de plaats van de wereld daarin. Maar de eerste zinnen van het eerste hoofdstuk deden me van gedachten veranderen. Het boek begint daar zo:

"Sitting alone at his table by the bar, Brian Arthur stared out the front window of the tavern and did his best to ignore the young urban professionals drifting in to get an early start on Happy Hour, [ ... on this late afternoon of March 17, 1987] ... . [Arthur] just wanted to silently sip his beer in frustrated rage. Stanford University professor William Brian Arthur, native son of Belfast, Northern Ireland, was at rock bottom." (Waldrop, (1992,p.15.)).

Brian Arthur is een Economie hoogleraar met een herkenbaar gevoel. Gelukkig, iets verder in het boek gaat Arthur naar huis waar zijn vrouw hem weer goede moed inpraat. Ook iets herkenbaars. Terwijl ik het zojuist gegeven citaat las in de winkel, bedacht ik me dat ik die naam Brian Arthur kende. De naam was ik tegengekomen in de oratie van mijn collega Luc Soete. Arthur wordt door Soete (1987) aangehaald als éen van de geestelijke vaders van het idee van pad-afhankelijke technologische ontwikkeling. De pakkende eerste zin en Soete's verwijzing naar Arthur maakten dat ik het boek kocht.

'Complexity' beschrijft op meeslepende wijze, net zo meeslepend als die eerste zin, de ontwikkeling van een onderzoeksinstituut in 
de Verenigde Staten, het 'Santa Fé Institute'. Brian Arthur raakt daar als econoom aan verbonden en hij krijgt er de erkenning die hij op 17 Maart 1987 nog niet had. Het onderzoeksprogramma van het Santa Fé Instituut richt zich op het fenomeen van zelf-organisatie in complexe systemen, zoals een economie of een kapitaalmarkt. Maar ik voer het boek in deze proloog van mijn oratie op, omdat het zo voortreffelijk het enthousiasme beschrijft waarmee de Santa Fé onderzoekers, inclusief een aantal Nobelprijs winnaars op verschillende gebieden, het ontginnen van een wetenschapsgebied ter hand nemen. Deze onderzoekers, dat beeld vormt het boek, zijn begeesterde mensen met een diep geloof in het nut van hun onderzoekswerk.

Wat ik met mijn rede beoog vandaag, is u eenzelfde beeld te geven van onderzoek op het terrein van Accounting of Berichtgeving.

Dat zal wellicht niet meevallen. Niet omdat er geen opwindend Accounting onderzoek is. Maar Accounting worstelt met een probleem van beeldvorming. Mensen die zich met Accounting bezig houden zijn niet begeesterd, eerder saai. Zo noemt 'The Economist' die mensen steevast 'beancounters'. En u kent vast wel de sketch uit 'Monty Python', waarin iemand bij een beroepskeuze adviseur binnenstapt na een reeks van testen. De adviseur, gespeeld door, als ik het mij goed herinner John Cleese, zegt dan:

$" .$. in our report here it says that you are an extremely dull person.

Om blijmoedig te vervolgen met:

"... [But] Where in most professions [that] would be a considerable drawback, in Accounting [it is] a considerable boon." (Bougen (1994, p.320,)).

Maar $u$, zeker de econoom en de accountant onder $u$, heeft natuurlijk al begrepen dat deze saaiheid een bestudeerde, en in het maat- 
schappelijke verkeer functionele, pose is. Vermeende saaiheid leidt niet tot de gedachte aan uitspattingen. Het leidt tot vermeende betrouwbaarheid. Als mensen dàt over een accountant denken dan is dat waardevol.

Dus, Accounting onderzoek is wel vitaal, opwindend en interessant. Ik zal u dat uitleggen.

Mijnheer de Rector Magnificus, Leden van het College van Bestuur van de Rijksuniversiteit Limburg, Vertegenwoordigers van de Open Universiteit,

Dames en heren collega's, studenten, familieleden en vrienden, Zeer gewaardeerde toehoorders,

\section{Inleiding}

In een recent invloedrijk artikel over de evolutie van per capita inkomensverschillen tussen landen schrijft de Amerikaanse econoom Bradford De Long ${ }^{1}$ dat de oorzaak van die verschillen ligt, en ik spreek de laatste twee woorden nadrukkelijker uit, in verschillen in, "... [the] application of [the] storehouse of industrial and administrative technology ..." (De Long (1988, p.1138). Ik ga het vandaag hebben over de rol in een economie en in economische ontwikkeling van 'administratieve technologie'. Mijn rede zal handelen over de economische rol van Berichtgeving. Daarbij helpt het Berichtgeving of Accounting voor te stellen als een vorm van technologie, administratieve technologie. Deze voorstelling als een gegeven nemend, wat is dan de economische rol van deze administratieve technologie? Dat is breed, maar accuraat, geformuleerd het thema van veel spannend, denk aan Santa Fé, onderzoek in Accounting. 
Ik zal aan de economische rol van Accounting of Berichtgeving enige beschouwingen wijden. Maar eerst zal ik trachten op bevattelijke wijze Accounting als vakgebied te duiden, de frase 'Accounting als technologie' uitleggen en enige motiverende Accounting fenomenen, motiverend voor onderzoek, de revue laten passeren. Tevens zal ik mijn betoog afbakenen ten opzichte van wat na mij nog gezegd gaat worden.

\section{Accounting of Berichtgeving}

Tot nu toe heb ik Accounting en Berichtgeving, als aanduiding van mijn gebied van specialisatie, bedrijfseconomie, i.h.b. berichtgeving, door elkaar gebruikt. Berichtgeving is de term die hier in Maastricht gebruikt wordt om de bedrijfseconomische specialisatie Accounting aan te duiden, en dat zal ik in de rest van mijn rede ook doen. Maar accounting begrijpt iedereen: in Nederland, en zeker daarbuiten. Vandaar het spel met accounting en berichtgeving in de titel van mijn rede.

In een recent artikel ${ }^{2}$ omschrijft Fischer Black Berichtgeving in zijn treffende stijl, als volgt:

"Accounting is the language that people within a firm can use to discuss its projects and progress with one another, and that they can use to tell outsiders what is happening in the firm, ...".(Black (1993,p.1)).

Het treffende in deze omschrijving is het gebruik van de woorden 'discuss' en 'tell'. Zo wordt Berichtgeving inderdaad gebruikt. Het vertellen over het wel of wee van een onderneming.

Waar Black taal ('language') gebruikt, gebruik ik liever technologie om redenen die ik zo dadelijk zal uitleggen. Wat ontbreekt in de omschrijving van Black, is dat Berichtgeving heel sterk steunt op systematisch verzamelde en vastgelegde, in de boekhouding van 
een onderneming geadministreerde financiële gegevens (vgl. Bindenga $(1991$, p.9)). Het is dus een taal of technologie voor het vastleggen van cijfers van financiële aard, met resultaat als centraal begrip. Dat vastleggen, het bepalen van het financiële resultaat, gebeurt daarbij op zo'n manier dat het uiteindelijk niet meer op kasbasis geschiedt. De vorm waarin deze technologie is geëvolueerd, het herverdelen van kasstromen in de tijd, wordt daarom in Angelsaksische landen aangeduid met 'accrual accounting' en in Nederland met 'Berichtgeving op basis van het toerekeningsbeginsel'. Er spelen nog meer beginselen, maar het toerekeningsbeginsel is het meest typerend. Vandaar dat ik het in de rest van de rede als generieke aanduiding zal gebruiken ${ }^{3}$.

Black's omschrijving parafraserend en aanvullend, is Berichtgcring dus nog iets beter te karakteriseren als:

de administratieve technologie die personen in een onderneming kunnen gebruiken om over projecten in ondernemingen en de vooruitgang- het financiële resultaat- daarvan met elkaar te praten en die zij kunnen gebruiken om mensen buiten de onderneming te vertellen wat er in de onderneming aan de hand is, wat het financiële resultaat is van de onderneming.

In Black's omschrijving is al een onderscheid te herkennen tussen Berichtgeving in een onderneming en Berichtgeving ten behoeve van buitenstaanders. Dat is het onderscheid tussen Interne- en Externe Berichtgeving. Binnen Externe Berichtgeving kan nog een aparte specialisatie onderkend worden: fiscale Berichtgeving, de administratieve technieken die de fiscus accepteert in haar conversatie met een onderneming, over het wel en wee ervan. Dat leidt tot de volgende specialisaties in Berichtgeving:

- externe Berichtgeving (Financial Accounting);

- fiscale Berichtgeving (Tax Accounting);

- interne Berichtgeving (Management Accounting); 
- (boekhouden) $)^{4}$.

Externe- en interne Berichtgeving en boekhouden behoren tot mijn leeropdracht. Fiscale Berichtgeving noem ik alleen omdat we volgend jaar hier in Maastricht van start gaan met een opleiding Fiscale Economie, waarin fiscale Berichtgeving een belangrijke rol speelt. Alhoewel er ook over fiscale Berichtgeving een oratie te vullen is (vgl. Kuijl (1990)) zal ik over dit gebied verder bijna niets zeggen.

Boekhouden heb ik tussen haakjes gezet. Het is zo verweven met de drie gebieden van specialisatie dat het moeilijk te zeggen is waar boekhouden ophoudt en Berichtgeving begint. Over boekhouden apart zal ik in de rest van mijn oratie dan ook verder niets zeggen. Blijven over, interne- en externe Berichtgeving. Interne Berichtgeving komt straks uitgebreid aan de orde in de oratie van mijn OU en RL collega Tom Groot.

Het beeld wordt dus het volgende: ik zal mij in het vervolg van mijn verhaal richten op externe Berichtgeving, in de vorm van jaarstukken (jaarverslag en jaarrekening, d.w.z. balans, resultatenrekening en toelichting) of tussentijdse verslagen. Behalve dan dat ik straks, om u te laten aanvoelen met wat voor empirische verschijnselen Berichtgevingsonderzoek zich bezighoudt, nog wel uitstapjes zal maken naar interne- en fiscale Berichtgeving. Ook zal ik wat zeggen over het vakgebied Accountantscontrole. Zoals Bindenga opmerkt: "Accountants houden zich ... vanuit hun functie in hoofdzaak bezig met controle van jaarrekeningen." (Bindenga $(1991$, p.2)). Dat wil zeggen met controle van externe Berichtgeving, zoals die is samengesteld door mensen binnen een onderneming, de controller, om mensen buiten de onderneming te vertellen wat er in de onderneming aan de hand is. Accountantscontrole als vakgebied is dus nauw verweven met externe Berichtgeving, maar tot mijn leeropdracht behoort het niet. 
Ik zal mij in het vervolg van deze rede beperken tot opmerkingen over externe Berichtgeving door "... private op winst gerichte ondernemingen." (de terminologie is van De Bondt (1993,p.V)). Dat is in zekere mate een beperking. Maar het wordt door de ontwikkeling naar privatisering van taken van de overheid en het zich steeds meer op resultaat richten van niet-private niet op winst gerichte organisaties, denk maar aan onze faculteit, een steeds minder relevante beperking.

\section{Berichtgeving als technologie}

Externe Berichtgeving voorstellen als administratieve technologie is accuraat en het heeft een aantal analytische en pedagogische voordelen. Mijn bedoeling is deze voordelen in de rest van de rede te exploiteren.

Technieken van externe Berichtgeving zijn uitgevonden ${ }^{6}$. Iemand heeft op een gegeven moment de techniek van het consolideren van de jaarrekeningen van moeder- en dochterondernemingen bedacht. Iemand heeft de netto-vermogenswaarde methode voor het waarderen van deelnemingen op een balans bedacht. Iemand heeft de techniek van het vormen van een voorziening voor latente belastingen uitgevonden. Technieken van externe Berichtgeving worden uitgevonden, gevraagd door de onderneming, en gebruikt door de onderneming in het gesprek met mensen buiten de onderneming over het wel en wee ervan. Analytisch en empirisch levert deze voorstelling de volgende interessante punten op. Hoe verloopt het proces van innovatie van technieken van externe Berichtgeving ? Wie zijn de uitvinders ? Verloopt het innovatie proces te snel of te langzaam ? Wat bepaalt de keuze van de gebruikende onderneming uit de verzameling van beschikbare technieken? Hoe verloopt het diffusieproces? 
Dit alles gebeurt op twee markten waarop de administratieve technieken in dit verband 'verhandeld' worden (vgl. schema 1). De markt tussen ontwerpers en gebruikende ondernemingen en de markt tussen de gebruikende onderneming en de mensen buiten de onderneming: aandeelhouders, crediteuren en werknemers.

Administratieve technieken zijn geen fysieke goederen. Het zijn idee-goederen, om een recente terminologie te gebruiken, bedacht door Romer (1993).

Externe Berichtgeving omvat dus, gelet op de voorgaande redenering, als vakgebied twee activiteiten, (1) het ontwerpen van ideegoederen, de administratieve technieken, en (2) de analyse van de keuze van dit soort idee-goederen door de ondernemingen.

Het zal u niet ontgaan zijn dat ik met een zeker genoegen het woord ontwerpen in de mond neem. Daar is mijn verleden, degenen die dat kennen zullen dat begrijpen, niet vreemd aan. Het geeft me ook de gelegenheid om de aandacht te vestigen op een wat minder bekend artikel van Herbert Simon, nu eens niet over begrensde rationaliteit, met als titel, "The science of design: creating the artificial", (Simon (1981, pp.128-159). Daarin betoogt Simon dat het leren van het ontwerpen van technieken, van ideegoederen, een belangrijke activiteit is van opleidingen als Bedrijfseconomie of Bedrijfskunde. Net zo eigenlijk als voor Economie als geheel, denk maar aan idee-goederen als het macro-economisch beleid van een overheid of de belastingpolitiek. De opmerking van Simon is dus waar voor Berichtgeving. En het is gemakkelijk in te zien dat dit ook zo is in andere deelgebieden van de Bedrijfseconomie. In het vakgebied Organisatie volgen voorstellen voor een adequaat ontwerp van ondernemingen elkaar in hoog tempo op (vgl. Van Witteloostuijn (1994,p.8)). In het vakgebied Financiering is de netto-contante waarde methode om de aantrekkelijkheid van investeringsgoederen te beoordelen een ontworpen idee-goed. 
Schema 1. Twee markten van technieken van externe Berichtgeving.

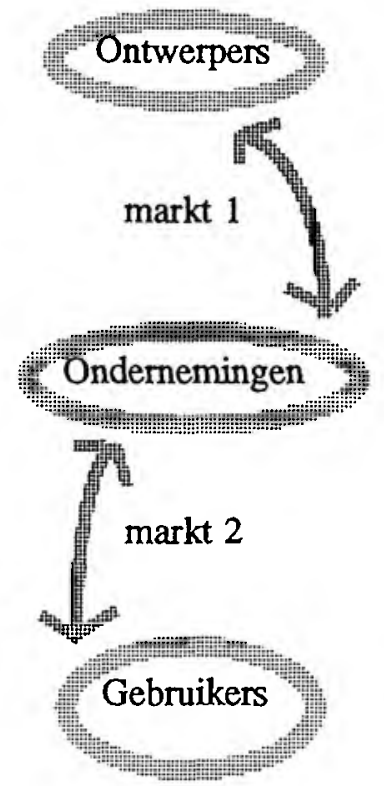


Faulhaber en Baumol (1988) hebben de geschiedenis van deze methode beknopt op papier gezet. Hier is ook een alternatief ideegoed in de maak, een methode om de aantrekkelijkheid van investeringsprojecten te bepalen op basis van technieken van optiewaardering (vgl. Dixit, Pindyck (1994) en Cheung (1993)). De techniek van optiewaardering is zelf ook weer een idee-goed, uitgevonden door Black en Scholes (1973)?

De notie dat er van ontwerpen van technieken van externe Berichtgeving, naast de analyse van de keuze en het gebruik ervan, sprake is, kan ook gebruikt worden om een zorg van mijn voorgangers Schreuder (1985) en Van de Poel (1987) weg te nemen. Die zorg bestond erin dat we als academische bedrijfseconomen wel kunnen begrijpen wat er gebeurt in bedrijven, maar geen bijdrage kunnen leveren aan de goede gang van zaken in bedrijven. De discipline van de markt dwingt bedrijven toch al tot optimaliseren - de beste keuze -, ook in de toepassing van idee-goederen zoals administratieve technieken. Zij gaan echter voorbij aan de mogelijkheid van onvoorzienbare kleinere en grotere echte innovaties, dat wil zeggen het ontstaan van nieuwe idee-goederen. $\mathrm{Er}$ is geen reden om aan te nemen dat de optimaliserende drang van de markt zich ook tot echte, onvoorzienbare, innovaties uitstrekt (vgl. Faulhaber en Baumol (1988) voor eenzelfde stellingname). Daarom kunnen ook academische bedrijfseconomen best een bijdrage leveren, en een nuttige, zelfs in het optimaliserend geweld van marktkrachten. Als je met het begrijpen wat er precies gebeurt, wat al ingewikkeld genoeg is, geen genoegen wil nemen tenminste.

Ik had $\mathrm{u}$ in de proloog beloofd dat ik zou proberen aan te geven waarom niet alleen de mensen van het Santa Fé instituut aan een spannend avontuur van onderzoek bezig zijn. Sterker, dat zoiets ook mogelijk is voor Berichtgeving. Ik grijp terug naar de opmerking van Bradford De Long, die ik aan het begin van mijn rede citeerde. De Long's artikel maakt deel uit van een fascinerende 
herleving van economisch en empirisch onderzoek naar de determinanten van economische groei. Ondernemingen, en vooral de manier waarop ondernemingen in elkaar gezet worden, tot in de details van de toegepaste administratieve technieken, spelen daarin een belangrijke rol. Hoe ondernemingen in elkaar gezet worden is daarom belangrijk, en dat maakt van Berichtgeving een fascinerend onderzoeksgebied.

De analyse van ontwerp en gebruik van technieken van externe Berichtgeving kan met verschillende gedragswetenschappen aangevat worden. In hetgeen volgt beperk ik mij tot een economische analyse ${ }^{8}$. Tom Groot zal straks nog andere mogelijkheden aangeven, zoals mij voorganger Jan van de Poel ook al deed in zijn oratie (Van de Poel (1988)).

Voor een goed begrip wil ik nog het volgende opmerken. Ik vat theoretische analyse, van economische aard, op als het bedenken van compacte, elegante, en overdraagbare verhalen over hoe de wereld in elkaar zit. Overdraagbaar in die zin dat empirische verschijnselen van verschillende aard op het gebied van externe Berichtgeving er mee 'aangepakt' kunnen worden. Het vermogen om dit soort 'verhalen' te bedenken, te toetsen, te gebruiken en door te geven is precies het comparatief voordeel van de academische wereld. Bovendien helpt het voorhanden zijn van goede theorie over verschijnselen van Berichtgeving ontwerpactiviteiten. Ik kom op dit alles straks terug.

\section{Motiverende fenomenen voor Berichtgevingsonderzoek}

\subsection{Opmerking vooraf}

Ik wil in deze paragraaf enige empirische verschijnselen tonen op het terrein van Berichtgeving, zoals omschreven door Fischer Black. Ik voeg het gebied van accountantscontrole daaraan toe. Ik wil laten zien wat onderzoekers op dit terrein nu eigenlijk willen 
begrijpen. Welke facetten van de wereld om ons heen probeert Berichtgeving te begrijpen? Naar al deze verschijnselen is dan ook meestal al intensief onderzoek gaande.

\subsection{Innovaties en externe Berichtgeving}

Zijn er hier innovaties ? Jazeker, heel veel. Mag ik u een wat ouder voorbeeld geven ? In 1926 publiceerde het Rotterdamse bedrijf Wm.H.Müller en Co., onder directie van een meneer Kröller als één van de eerste Nederlandse ondernemingen een geconsolideerde jaarrekening 9 . U hoort hier inderdaad de herkomst van de naam van het beroemde museum op de Hoge Veluwe. Dr. Kröller was gehuwd met mevrouw Müller. Een geconsolideerde jaarrekening is een balans en resultatenrekening waarin alle dochterbedrijven en de moederonderneming zijn geaggregeerd. De accountant van Müller en Co. was, pas aangetreden, Price-Waterhouse. Het was ook Price-Waterhouse dat in 1902 de eerste Amerikaanse consolidatie doorvoerde, de eerste ter wereld, die van U.S.Steel. Een innovatie van administratieve techniek, een ideegoed, waarvan we hier bovendien de export zien plaatsgrijpen. (Vgl. Edwards (1991) voor het verhaal van US Steel en de eerste Engelse consolidatie in 1910). Een onderzoeksvraag die zich hier opdringt: hoe verliep de innovatie van de consolidatietechniek en hoe verspreidde de techniek zich ${ }^{10}$.

\subsection{Keuze van externe Berichtgeving}

Als je vervolgens de vraag stelt: wat zijn de determinanten van de keuze voor consolidatie of niet-consolidatie bij ondernemingen, betreed je een heel rijk en breed gebied van empirische verschijnselen van Berichtgeving. Het is het gebied van Stelselkeuze. Stelsel staat voor de gebruikte verzameling van technieken van Berichtgeving door een onderneming. Het introduceren van, bijvoorbeeld, de techniek van consolidatie door de ondernemingsleiding is een partiële stelselkeuze. Economische analyse is een krachtige weg om de determinanten van zo'n beslissing bloot te leggen, en empirische 
toetsing van ideeën daarover mogelijk te maken. Ik kom daar zo op terug ${ }^{11}$.

\subsection{Regulering van externe Berichtgeving}

Regulering op het terrein van externe Berichtgeving betekent het opleggen van administratieve technologie. Een onderneming wordt opgedragen, hoe aan de mensen buiten de onderneming verteld moet worden wat er in de onderneming aan de hand is. Bijvoorbeeld, gij zult consolideren. De regulerende instantie grijpt dus in op markt 2 van schema 1. In Nederland is dit soort regulering door de overheid op gang gekomen in 1971. In Nederland zijn de regelgevers de overheid en de Raad voor de Jaarverslaggeving ${ }^{12}$. De puzzel voor onderzoekers is hoe regulering zich hier verhoudt tot niet-regulering. Er is een verzameling van beschikbare technologie voor externe Berichtgeving. Regulering betekent inkrimping van deze verzameling tot een deelverzameling. Die inkrimping is ook een ontwerpactiviteit, deze keer door de overheid. Er bestaan dan technieken die de onderneming niet meer mag gebruiken als de onderneming met mensen buiten de onderneming wil communiceren. Omgekeerd legt regulering vaak verplichtingen op aan ondernemingen die niet direct met buitenstaanders willen communiceren. Die worden dan toch gedwongen een bepaalde verzameling technieken te gebruiken. Is dit soort opgelegd handelen verstandig ? Zouden zich niet spontaan aanvaardbare technieken hebben ontwikkeld $^{13}$ ? Dit alles dwingt tot een economische analyse van de markt voor externe Berichtgeving tussen ondernemingen en buitenstaanders en de regulering daarvan ${ }^{14}$.

\subsection{Toerekening van overhead kosten in interne Berichtgeving}

De wijze van toerekening van overhead kosten aan de produkten die een onderneming voortbrengt is een probleem van interne Berichtgeving. Het wordt bovendien door de voortschrijdende ontwikkeling in fysieke technologie een steeds groter probleem. Direct toerekenbare kosten worden van steeds minder belang. Deze 
laatste observatie heeft aanleiding gegeven tot een omvangrijke ontwerpactiviteit in de literatuur met als produkt de 'activity based costing' technologie. De intentie van de $\mathrm{ABC}$ ontwerpers is een techniek te ontwikkelen die een nauwkeurige toerekening van alle kosten aan produkten mogelijk maakt ${ }^{15}$. Als dat niet gebeurt subsidiëren feitelijk slecht draaiende produkten, produkten die het goed doen. Door dit te voorkomen verbetert de bedrijfsvoering. Maar dat is nog niet zo zeker. Ook andere overwegingen kunnen spelen op dit punt. Dat is te zien in een recent artikel van Esther Gal-Or (Gal-Or (1993)). Zij pleit er voor de verdeling van overhead kosten te gebruiken als competitief wapen. Dat wil zeggen, de verdeling te laten afhangen van de vorm van de markt waarop de produkten, waaraan de kosten worden toegerekend, afgezet worden. In bepaalde markten moet je agressief zijn, minder overheadkosten toerekenen dus, in andere niet. Gal-Or's artikel is een voorbeeld van pure ontwerpactiviteit geholpen door inzichten uit de economische theorie over markten. De analyse hier moet vervolgens de vorm aannemen van een beschouwing van de omstandigheden waaronder ondernemingen de mogelijke technieken van toerekening van overhead kosten toepassen ${ }^{16}$.

\subsection{Risicoanalyse en het controleprogramma van accountants}

Controlerende accountants nemen de hen voorgelegde jaarrekeningen, opgesteld door het management van een onderneming, grondig onder de loep. Accountants, in het jargon, attesteren de jaarrekening. Ze zien erop toe dat de jaarrekening een getrouw beeld geeft van de toestand van de onderneming. Of het verhaal dat de onderneming over zichzelf vertelt klopt. Daartoe werken accountants een controle programma af. Ook hier is dus weer sprake van een idee-goed, een technologie, een collectie van technieken ${ }^{17}$. Ook hier stelt zich de vraag waar en onder welke omstandigheden deze technologie ontwikkeld wordt en vervolgens gebruikt. Eén vorm van het samenstellen van een controleprogramma voor de jaarrekening is het toepassen van een techniek die Risicoanalyse 
heet. Het gaat om het risico van het voorkomen of niet-detecteren van onvolkomenheden in een jaarrekening. Eén van de risico elementen is het bestaan van gebreken in de administratieve organisatie in de onderneming. Eenmaal de risico elementen goed ingeschat, volgt daaruit een controleprogramma. Dat is de technologie. Het interessante empirische verschijnsel hier is hoe deze techniek wordt toegepast. Verandert bijvoorbeeld het controleprogramma over tijd onder invloed van veranderingen in het totale risico (Vgl. Quadackers, Mock, Maijoor (1994)).

\subsection{Fiscale- en externe Berichtgeving.}

De verzameling van technieken van externe Berichtgeving die gebruikt kunnen worden voor Berichtgeving aan de fiscus is ook een deelverzameling van de verzameling beschikbare technieken. In sommige landen, Duitsland en Frankrijk bijvoorbeeld is die beperking miniem. De verzameling technieken voor de fiscus definieert daar de verzameling technieken die in externe Berichtgeving gebruikt mogen worden. In Nederland, Engeland en de USA is dat anders. Daar is er duidelijk sprake van twee verzamelingen technieken. Enerzijds is er de gereguleerde verzameling van technieken voor de commerciële Berichtgeving en anderszijds die voor de fiscale Berichtgeving. Er zijn daar dus twee ontwerpers in het spel, en in een land als Duitsland maar éen. Een analytische en empirische kwestie hier is dan de vraag of deze verschillen tussen commerciële en fiscale berichtgeving (vgl. Wolfson (1993,p.321)), een effect hebben op de eigenschappen van de gerapporteerde commerciële winst. Zeg, op het informatiegehalte ervan voor de gebruikers. Een andere kwestie is of er een effect is op de houding van ondernemingen ten opzichte van belasting-planning (vgl. ook Scholes en Wolfson (1992)).

\subsection{Afsluitende opmerking}

Deze lijst met empirische verschijnselen, van diverse aard, die onderzoek motiveren, valt heel lang te maken. Dat kan op alle 
deelgebieden van Berichtgeving. Op al die deelgebieden is er dus ruimte te over voor reflectie en activiteit op ontwerpgebied en zijn er analytische en empirische vragen bij de vleet. Genoeg stof voor onderzoek dus. Maar in het vervolg van mijn rede zal ik mij nu richten op een paar 'grotere' vragen.

\section{Economische groei en Berichtgeving als technologie}

Een 'grote' vraag die mij al langer intrigeert is, wat is de macroeconomische rol van berichtgeving ${ }^{18}$ ? Dat is een moeilijk te beantwoorden vraag. Maar een zich snel ontwikkelende nieuwe literatuur over de determinanten van economische groei, biedt een handvat om een begin van antwoord te geven ${ }^{19}$. Eén van de meest prominente auteurs in die literaturur is Paul Romer ${ }^{20}$. Het is op zijn gedachtengoed over economische groei dat ik me nu richt.

Romer en zijn collega's hebben het onderzoek naar de determinanten van economische groei opnieuw op gang gebracht, onder meer gebruik makend van het werk van Angus Maddison van de Rijksuniversiteit Groningen. Diens (zeer) lange termijn beschrijving van economische groei in een reeks van landen, leidde bijna vanzelfsprekend tot de vraag wat de waar te nemen groeiverschillen in Maddison's reeksen kon verklaren. De eerste die deze vraag hardop stelde was Baumol (1986), en Bradford De Long's opmerking over administratieve technologie aan het begin van mijn rede, komt uit een reactie van De Long op Baumol (1986). Baumol en De Long's discussie, tezamen met artikelen van Romer (1986) en Lucas (1988) heeft dan een nieuwe golf van literatuur doen ontstaan, met als simpele maar eminent belangrijke vraag: wat verklaart relatieve verschillen in groei in inkomen per capita tussen landen? Romer's bijdragen aan deze literatuur zijn fundamenteel.

In zijn meest recente bijdragen ontwikkelt Romer de gedachte dat één van de belangrijke determinanten van economische groei het 
ter beschikking hebben en ontwikkelen van idee-goederen is. De voor economische groei belangrijkste idee-goederen verschillen van fysieke goederen doordat zij maar zwak van eigendomsrechten voorzien kunnen worden en vooral dat ze niet-rivaliserend in gebruik zijn. Veel mensen kunnen een idee-goed tegelijk gebruiken. Zoals Romer het uitdrukt:

"The idea behind the transistor, the principle behind internal combustion, the organizational structure of the modern corporation, the concepts of double-entry bookkeeping- all these pieces of information and many more like them, have the property that it is technologically possible for everybody and every firm to make use of them at the same time. In the language of public finance, ordinary goods are rival goods, but information ['idee-goed'] is non-rival." (Romer (1994,p. 12)).

Idee-goederen zijn volgens Romer de motor van economische groei, precies door hun niet-rivaliserend karakter. Verschillen in economische groei bestaan- en kunnen opgeheven worden - door verschillen in inzet van idee-goederen tussen landen. Bovendien is het voortbrengen van dit soort idee-goederen volgens Romer een endogeen gebeuren: "Technological advance comes from things that people do." (Romer (1994,p.12)). Dat wil zeggen, het is een resultante van ontwerpactiviteiten.

In het empirische deel van deze nieuwe groei literatuur zijn vervolgens een paar studies te vinden, die suggestief zijn in het kader van het thema van deze paragraaf. Er is het werk van King en Levine (1993) en van Murphy, Shleifer en Vishny (1991).

King en Levine (1993) onderzoeken het effect van een idee-goed op groeiverschillen tussen landen. Dat idee-goed is de graad van ontwikkeling van het financiële systeem, inclusief de beheersstructuur van ondernemingen (en dus Berichtgeving), in een economie. 
De empirie van King en Levine is recht toe recht aan. Ze regresseren voor een cross-sectie van 80 landen economische groei tussen 1960 en 1989, op een aantal uit de nieuwe groeiliteratuur bekende determinanten van groei, plus een aantal zelf ontwikkelde maatstaven van de ontwikkeling van het financiële systeem in die landen. De bevindingen zijn voorzichtig positief. Er lijkt een verband van financieel systeem naar economische groei te zijn.

De andere genoemde studie, die van Murphy, Shleifer en Vishny (1991) onderzoekt of economische groeiverschillen tussen landen samenhangen met keuzemogelijkheden voor het aanwenden van produktief talent door personen in die landen. In hun gedachtengang is het zo dat economieën die veel ruimte bieden voor carrières in 'rent seeking', vergeleken met economieën met carriëre mogelijkheden in ondernemende activiteiten, slechtere groeiprestaties zullen leveren ${ }^{2 !}$. 'Rent' staat voor een niet economisch te rechtvaardigen overwinst. Het belang van twee groepen 'professionals' in een economie nemen zij als additionele determinanten op in een regressie met economische groei tussen 1970 en 1985 voor 91 landen als afhankelijke variabele. De additionele determinanten zijn, de relatieve omvang van de beroepsgroep der meesters in de rechten en de relatieve omvang van de beroepsgroep der ingenieurs. Meesters in de rechten staan voor 'rent seeking' en ingenieurs voor produktieve activiteiten. Het verwachte teken voor meesters is dus negatief, voor ingenieurs positief. Hun conclusie luidt: "Lawyers are indeed bad, and engineers good for economic growth." (Murphy, Shleifer, Vishny (1991, p.529)).

Er zijn ook behoorlijke verschillen in de relatieve omvang van het accountantsberoep tussen landen, wat als maatstaf voor de mate van berichtgevingsactiviteiten in een land zou kunnen gebruikt worden. Dat is te zien in de volgende tabel ontleend aan Morse (1993, table 1). Morse berekende voor 1987/88 de fractie leden van nationale accountantsorganisaties op de totale bevolking voor 
62 landen. Tabel 1. toont voor 16 landen de verschillen. De verhouding Verenigd Koninkrijk/België bijvoorbeeld bedraagt 84 op 1.

Tabel 1. Fractie accountants in totale bevolking voor 16 geselecteerde landen.

New Zeeland

Singapore

Canada

Verenigd Koninkrijk

Verenigde Staten

Hong Kong

Luxemburg

Nederland

Italië

Frankrijk

Spanje

West-Duitsland

België

Zuid-Korea

Indonesië

Marokko
0,004366

0,002011

0,001799

0,001694

0,001046

0,000695

0,000630

0,000450

0,000386

0,000299

0,000110

0,000096

0,000069

0,000048

0,000020

0,000005

Wat is het effect van deze verschillen op economische groei verschillen tussen landen ? Ik geef natuurlijk meteen toe dat er heel wat problemen kleven aan dit soort gegevens.

In ieder geval vestigt de bovenstaande analyse en vooral dan Romer's bijdrage, de aandacht op het potentiële positieve economische effect van de verdere ontwikkeling van idee-goederen zoals 
Berichtgeving. Het lijkt daarom van belang om een institutioneel kader te bedenken (weer een idee-goed) om innovatie hier te bevorderen. Daar kom ik in het volgende op terug.

Waarom is er een effect van Berichtgeving op economische ontwikkeling ? Het op dit moment sterkste verhaal daarover, de meestbelovende economische theorie erover, komt nu aan de orde.

\section{6. (Gereguleerde) Stelselkeuze en Berichtgeving als technologie}

De voorgaande beschouwing over de macro-economische rol van (externe) Berichtgeving, inclusief accountscontrole, is éen manier om als econoom naar Berichtgeving te kijken. Een andere manier is om als econoom de vraag te stellen: waarom is er Berichtgeving door en in ondernemingen ? Waarom wordt gebruik gemaakt van administratieve technologie op dit terrein ? Wat zijn de 'baten' van het gebruik ervan?

Nieuwe ontwikkelingen in de economische theorie van de onderneming hebben de laatste 17 jaar, en dan neem ik Watts (1977) als de eerste toegepaste bijdrage, een vloed van theoretisch en empirisch $^{22}$ onderzoek naar deze vragen op gang gebracht. Veel van dit onderzoek, net zoals de hele economische theorie van de onderneming $^{23}$, is terug te voeren op Coase (1937). Coase (1990) zegt zelf over Berichtgeving:

"The theory of the accounting system, is part of the theory of the firm.",

en,

"... it seems reasonable to suppose that an increased understanding of the part which accounting plays within the firm will not be without some advantage to accounting." (Coase (1990,p.12)). 
Het is bekend dat Coase ondernemingen ziet ontstaan als dat een besparing oplevert in contractkosten tussen marktpartijen. Volgens Ball (1989), in een fundamentele bijdrage, is Berichtgeving (inclusief accountantscontrole) een collectie van technieken die in ondernemingen dit vermogen tot het besparen op contractkosten mede doet ontstaan. Ball's (1989) redenering is een aanvulling op het werk dat zijn oorsprong vindt in Watts (1977) en dat geculmineerd is in het 'Positive Accounting Theory' boek van Watts en Zimmerman (1986). Dat boek vat veel, ook nadrukkelijk empirische, literatuur samen waarin de keuze van technieken van externe Berichtgeving door ondernemingen in de jaarrekening, de stelselkeuze met andere woorden, ex-post gebeurt. Dat wil zeggen, gegeven het bestaan van allerlei andere contractuele mechanismen, zoals beloningscontracten met het management en contracten met crediteuren, ook gericht op het beheersen van contractkosten $n^{24}$. In zijn oratie concentreerde Van de Poel (1988) zich op de ex-post opportunistische keuze van berichtgevingstechnologie, gegeven de andere contracten.

Ball (1989) en Watts en Zimmerman (1990) betogen in aanvulling op de ex-post benadering, dat de keuze van de vormen van externe Berichtgeving en de keuze van de andere contracten tegelijkertijd plaatsvindt. Deze keuzes leiden dan tot een efficiënte, maar niet helemaal complete, gelet op de complexiteit van de situatie, exante oplossing van het contractkosten probleem.

De ex-ante benadering van de keuze van externe Berichtgeving technieken heeft vier belangrijke implicaties. Een eerste implicatie is dat externe accountants de deskundigen zijn die de contracten ex-post compleet maken op het punt van de keuze van Berichtgeving technieken.

Een empirische voorspelling, en tweede implicatie, is dat stelselkeuze dus 'rationeel' kan verschillen tussen ondernemingen, 
gericht op het beheersen van contractkosten in elke specifieke situatie. De eerste empirische studies langs deze lijnen zijn Skinner (1993) en Anderson, Francis en Stokes (1993).

De derde implicatie is dat de rol van regulering, die ik al eerder voor u geschetst heb, anders wordt. Om te voorkomen dat de regulerende instantie, ex-ante niet gepaste Berichtgeving technieken oplegt aan ondernemingen, zou de regulerende instantie- de wetgever en vooral de RJ in Nederland- zich eerder moeten gedragen als een gespecialiseerde innovator en conservator van technieken van Berichtgeving, waarbij ondernemingen te rade kunnen gaan (vgl. Ball (1989) en eerder al Wilson (1982)).

De vierde implicatie is makkelijk over het hoofd te zien. Die is dat de bestaande externe Berichtgeving op basis van het toerekeningsbeginsel, 'accrual financial accounting', een belangrijke rol speelt bij de beheersing van contractkosten in ondernemingen.

Een tussenopmerking: naast de rol die externe Berichtgeving op basis van het toerekeningsbeginsel speelt in het beheersen van contractkosten in ondernemingen, is er de rol van externe Berichtgeving als indicator van de waarde van ondernemingen of de aandelen daarvan. Dit onderwerp hoort ten dele meer thuis in een verhaal over financiële analyse, dus ik zal er hier niet lang bij stilstaan. Ik wil alleen wijzen op een belangrijke ontwikkeling in de literatuur waarin externe Berichtgeving op basis van het toerekeningsbeginsel, als een rechtstreekse maatstaf van waarde van een onderneming wordt geanalyseerd en niet zoals gebruikelijk, als een indicator, onrechtstreeks ${ }^{25}$, van waarde. Penman (1991 en 1992) heeft over deze nieuwe ontwikkeling al een prachtig overzicht geschreven.

Het zal $u$ opvallen dat als dit alles een beschrijvende theorie van de wereld is, de rol van de externe accountant ook verandert. Als de 
regulerende instantie eerder gericht is op conservering van toepasbare, en redelijke, technieken van Berichtgeving en niet als een strikte beperker van technieken, ontstaat bij de accountantskantoren een mogelijkheid, evenzeer als zij dat doen met hun accountantscontrole technieken en hun management accounting en fiscale adviezen, eigen pakketten van externe berichtgeving technieken te ontwikkelen en op de markt te brengen. Daaruit kunnen de gebruikers, de aandeelhouders, de crediteuren, dan in ex-ante overleg met het management van de onderneming dan uit kiezen ${ }^{26}$. Zo zou de regulerende instantie in deze opzet ten opzichte van de aanbieders en vragers van externe Berichtgeving fungeren als een 'review panel' zoals dat in het Verenigd Koninkrijk bestaat, maar dan van de technieken en niet zozeer van jaarrekeningen.

Als $u$ er aan twijfelt dat er ook nu nog innovaties op dit terrein plaatsvinden, kan ik $\mathrm{u}$ het volgende voorschotelen. Mijn naaste collega Henk Brink (1991) heeft voorgesteld ondernemingen twee jaarrekeningen te laten publiceren: een juridische en een bedrijfseconomische. Collega Hoogendoorn (1993) volgt in zijn recente Amsterdamse oratie Brink daarin met enige aanvullingen. De juridische jaarrekening zou dan een rol spelen in de bescherming van crediteuren en bij de dividenduitkering, terwijl de bedrijfseconomische jaarrekening er voor het inzicht zou moeten zijn, anders opgesteld en andere technieken gebruikend. Een ander voorbeeld. Mijn collega Bindenga heeft in zijn recente, al aangehaalde, Rotterdamse oratie voorgesteld de bedrijfseconomische jaarrekening, opgesteld op basis van het toerekeningsbeginsel, aan te vullen met een (getalsmatige) visie van de ondernemingsleiding op de waarde van de onderneming op basis van de begrote toekomstige netto-kasstromen: een extra staat dus. Brink, Hoogendoorn en Bindenga zijn hier aan het ontwerpen, aan het innoveren. Dit soort innoverende activiteiten bestaan dus, en zijn dus perfect denkbaar, georganiseerd binnen accountantskantoren. Het aantal 
idee-goederen zou zich in een competitief proces, en dat is heel belangrijk, verder ontwikkelen ${ }^{27}$.

Dit alles sluit natuurlijk aan bij mijn opmerkingen in de vorige paragraaf over de noodzakelijke rol van voortdurende innovatie en verdere ontwikkeling van idee-goederen in economische ontwikkeling. Het ligt dan ook voor de hand dat accountantskantoren dit soort innovatie ter hand gaan nemen binnen de firma's, op internationaal niveau. Daarmee kom ik bij een volgende beschouwing. In die beschouwing zult $u$ een bijzondere bron van innovatie van technieken van externe Berichtgeving ontdekken.

\section{Europese aspecten van Berichtgeving als technologie}

Ik heb er net op gewezen dat verklarend onderzoek op het terrein van externe Berichtgeving een geschiedenis heeft van ongeveer 20 jaar. Gedurende dezelfde periode heeft zich in Europa een zeer belangrijke ontwikkeling voorgedaan op het terrein van de regulering van externe Berichtgeving in de vorm van het vennootschapsrecht harmonisatie programma van de EG (nu EU) en de activiteiten van het door de accountantsverenigingen beheerste 'International Accounting Standards Committee'. Karel van Hulle geeft van deze ontwikkelingen regelmatig leesbare overzichten (vgl. bijvoorbeeld Van Hulle (1993)). Alexander en Nobes (1994) hebben door deze ontwikkelingen een innovatief handboek - een Europese inleiding tot externe Berichtgeving - kunnen schrijven.

Deze twee ontwikkelingen gericht op harmonisatie hebben gelet op mijn betoog, een belangrijk paradoxaal en daardoor heilzaam effect. Er is een hele literatuur ontstaan waarin externe berichtgevingstechnologie, ontwikkeld in relatieve isolatie in verschillende landen, vergelijkenderwijs wordt bestudeerd. Het heeft de interesse voor systemen van externe Berichtgeving en de variëteit daarin sterk verhoogd. Dat heeft in het licht van mijn twee vorige para- 
grafen interessante gevolgen. Van Hulle (1993) beschrijft een hele reeks van gevallen waarin ondernemingen in land $X$, de externe berichtgevingstechnologie ontwikkeld in land $\mathrm{Y}$ gebruiken. Met andere woorden, en paradoxaal, een proces gericht op harmonisatie heeft in feite de keuzemogelijkheden vergroot voor ondernemingen. In de mate dat dit tot betere ex-ante oplossingen heeft geleid binnen ondernemingen bij de terugdringing van contractkosten en zo een gunstig effect heeft op economische ontwikkeling, is dat een gunstig verschijnsel.

In het licht van dit alles zal het $u$ duidelijk zijn dat wij in het onderwijs de studenten niet alleen in aanraking brengen met de Nederlandse verzameling van externe Berichtgeving technieken. Het onderwijs op dit terrein schoeien we op internationale leest.

\section{Comparatieve voordelen}

Ik wil eerst stilstaan bij het comparatief voordeel van de administratieve technologie Berichtgeving, in ondernemingen, zoals we die nu kennen. Die technologie heeft een hoge overlevingswaarde. Het is dit jaar 500 jaar geleden dat in Venetië een eerste gedrukte verhandeling erover verscheen ${ }^{28}$. Maar dat neemt niet weg dat er druk is tot voortdurende innovatie in de technologie. Berichtgeving maakt deel uit van de beheersstructuur ('Governance Structure') van ondernemingen. Net als instituties zoals de Raad van Bestuur en de Raad van Commissarissen en nieuwe ideeën zoals een Audit Comité. Maar ook behoren daartoe de arbeidsmarkt voor managers, en de kapitaalmarkt voor ondernemingen. Berichtgeving zal dus gedwongen zijn tot innovatie door het samenspel en de concurrentie $e^{29}$ met andere zich ontwikkelende elementen in de beheersstructuur van ondernemingen en onder druk van veranderende economische omstandigheden. 
Een tweede comparatief voordeel dat ik al ter sprake bracht is dat van academisch Berichtgevingsonderzoek. Wat is ons comparatief voordeel ? Ik denk, het ontwikkelen of gebruiken van elegante ${ }^{30}$, compacte verhalen, theorieën, over hoe de wereld op het gebied van Berichtgeving in elkaar zit en het toetsen daarvan om de beste verhalen te vinden. En ook, en niet minder belangrijk, deze verhalen, over te brengen op studenten en het hen proberen aan te leren dit soort verhalen zelf te ontwikkelen (vgl. ook Wilson (1994)). Bovendien, en daar maak ik de cirkel mee rond, is een beter inzicht in hoe de wereld op het gebied van externe Berichtgeving in elkaar zit, de beste voedingsbodem voor innoverende activiteiten, het ontwerpen van nieuwe technieken.

\section{Slotopmerking}

Ik heb getracht $\mathrm{u}$ een beeld te schetsen van Berichtgeving als spannend gebied van onderzoek, door te wijzen op twee aspecten van dat soort onderzoek, ontwerp en analyse van gebruik, en wat daarmee samenhangt. Ik heb geprobeerd de nadruk te leggen op het belang van Berichtgeving en innovaties daarin voor ondernemingen. Zo zijn drie grote vragen aan de orde geweest. Waar komt de administratieve technologie Berichtgeving vandaan ? Wat maakt deze technieken bruikbaar? Tenslotte, wat is het effect van deze technieken ? Ik heb mij hoofdzakelijk beperkt tot externe Berichtgeving. Ik heb mij ook beperkt tot de economische analyse van Berichtgeving als technologie.

Ik wil drie observaties uit mijn rede nog eens benadrukken. Economische analyse geeft aan dat innovatie van technieken van Berichtgeving belangrijk is. Het maakt ondernemingen en het verder bestaan daarvan mogelijk en heeft zo een belangrijke impact op economische ontwikkeling. Ten tweede mag regelgeving op dit terrein dus niet zo opgezet zijn dat het dit noodzakelijke proces van innovatie hindert. Integendeel het moet innovatie bevorderen. En 
ten derde zie ik in dit proces van innovatie een belangrijke rol voor accountantskantoren.

Met het thema Berichtgeving als technologie, als idee-goed, heb ik geprobeerd $\mathrm{u}$ beter uit te leggen wat Berichtgeving behelst. Het is mij, als lid van het directorium van het 'Maastricht Accounting and Auditing Research Center' (MARC), natuurlijk ook niet ontgaan dat voor economisch onderzoek naar ontwikkeling en gebruik van fysieke technologie en fysieke goederen bij diverse instanties veel geld beschikbaar is. Maar daar heb ik maar heel even aan gedacht.

\section{Dankwoord $^{31}$}

Ik wil mij in de eerste plaats richten het College van Bestuur van de RL. Ik wil hen bedanken voor het in mij gestelde vertrouwen, zoals dat blijkt uit mijn benoeming.

Hooggeleerden De Brabander en Jegers; Bert en Marc, van jullie heb ik veel geleerd aan het begin van mijn academische loopbaan. Ik ben jullie daar zeer erkentelijk voor.

Hooggeleerden Schreuder en Van de Poel; Hein en Jan, ik dank jullie voor de gelegenheid en de tijd om mij het vakgebied Berichtgeving eigen te maken. Jan dank ik ook voor zijn aanvallen van creativiteit waardoor zaken, zoals het MARC, in een stroomversnelling terecht kwamen, en als promotor.

Hooggeleerden Beek, Brink, Groot, Kuijl, Maijoor, Schilder en verdere collega's van de sectie Berichtgeving, omvattende ook het MARC, en de postdoctorale opleidingen, inclusief de curatoria. Wij hebben onszelf drie taken gesteld, al praten we er nooit zo expliciet over. We willen jonge mensen heel goed opleiden als bedrijfseconoom of bedrijfskundige op het terrein van berichtgeving en verder als accountant of controller. Daarnaast willen we 
het onderzoek op het terrein van Berichtgeving weer laten aansluiten bij het internationale onderzoek. Tenslotte willen we het jonge 'Maastricht' prominent op de Nederlandse 'accountancy agenda' zetten. Het eerste is gelukt. Het tweede, mede door de oprichting van MARC en de rol daarin van onze Amerikaanse èn Limburgse collega's Merchant, Mock en Zeff, is op een oor na gevild. Het derde is met gezwinde pas geregeld. Laten we met volle kracht waar nodig aan deze doelen verder werken. Ik beleef er veel plezier aan dat met jullie samen te doen.

Geachte vertegenwoordigers van het bedrijfsleven. $\mathrm{U}$ bent onze belangrijkste afnemer. Ik citeer uit Bouma's oratie: "Het is voor een bedrijfseconomisch theoreticus soms moeilijk ... begrijpelijke taal te spreken tot degenen, die het voorwerp zijn van zijn studie en die tevens moeten worden gezien als de ... afnemers van zijn theoretische produkten, alsmede als leveranciers van zijn grondstof." (Bouma (1967)). Bouma heeft daar wel gelijk in. Ik zal proberen dat probleem te verhelpen door mijn contacten met $u$ sterk te intensiveren. $U$ hoort nog van mij.

Studenten, voor $\mathrm{u}$ een woord van aansporing. Ik zou $\mathrm{u}$ willen vragen niet te sterk aan te dringen op het krijgen van onderwijs in direkt toepasbare kennis. $U$ verkeert in een tempel van wetenschap. Ons ultieme doel is u conceptuele kennis met een lange levensduur bij te brengen die $u$ zal toelaten de omgeving waar $u$ straks opereert beter te begrijpen en te beïnvloeden, daar wees ik al op in het voorgaande.

Tot slot een woord van dank voor mijn gezin, en één voor mijn familie en vrienden.

Ik heb gezegd. 


\section{Noten}

1. De Long (1988) maakt deel uit van een zich ontwikkelende recente literatuur over de determinanten van economische groei. Ik kom daar in sectie 5 nog op terug.

2. Black (1993) is, ik loop vooruit, een zuiver voorbeeld van ontwerpen (innovatie) in externe Berichtgeving.

3. 'Accrual accounting' is geen afgerond geheel. Het evolueert, zoals ik verderop in de rede ook zal betogen. Voor een recent en veelvormig overzicht van 'issues' en 'controversies' op dit terrein, vgl. Zeff en Dharan (1994).

4. Voor een gelijkaardige indeling vanuit een V.S. perspectief, vgl. (Hamada, et.al., (1988, sectie 2)).

5. De Bondt (1993) doet een geslaagde poging om heel wat Engelstalige terminologie in de nieuwe theorie over de onderneming te vertalen in het Nederlands, zoals Barten (1989) dat ook al deed voor de econometrie. De Bondt en Barten zijn beiden verbonden aan de KU Leuven.

6. Als u als leek een lucide inleiding wilt inzien over wat voor een technieken er op dit terrein bestaan, dan is Whittington (1991) (uit Engeland) zeer geschikt. Een meer gevorderde lucide inleiding is het Australische Whittred en Zimmer (1992).

7. Fischer Black (1989) vertelt het verhaal van de uitvinding van de optie waardering formule.

8. Voor een sociologische en ook empirische analyse van de keuze van technieken van externe Berichtgeving, vgl. Mezias (1990).

9. Deze paragraaf gebruikt wat resultaten van lopend onderzoek van Jos Blommaert en mijzelf.

10. Nog een voorbeeld: Watts en Zimmerman (1983) reconstrueren de uitvinding van de externe accountant. Zo zijn er in de literatuur meerdere bijdragen. Tot nu toe ontbreekt in de literatuur een artikel zoals Faulhaber en Baumol (1988) waarin al dit materiaal geordend wordt behandeld.

11. Bij die nadere behandeling in sectie 6 geef ik ook verwijzingen naar relevant onderzoek.

12. Vgl. voor de geschiedenis van de regulering van externe Berichtgeving in Nederland, Zeff, van der Wel en Camfferman (1992). Een heel goede samenvatting van de huidige wettelijke regels voor externe Berichtgeving in Nederland is Klaassen en Zevenboom (1993). De Raad voor de Jaarverslaggeving geeft losbladig Richtlijnen voor de Jaarverslaggeving uit (RJ (s.d.)).

13. Vgl. bijvoorbeeld Benson (1989) voor een beschrijving van de spontane ontwikkeling van wetgeving op economisch terrein in de Middeleeuwen, die dan later gecodificeerd werd.

14. Vgl. voor een goede poging daartoe, Easterbrook en Fischel (1984), die veel theoretisch en empirisch onderzoek behandelen. Vgl. ook, voor een meer recent overzicht, Maijoor (1991, hfdstk.2). 
15. Voor een vroege beschrijving en kritiek van ABC, vgl. Noreen (1987). Voor een recente bijdrage van de ontwerpers van ABC, vgl. Cooper en Kaplan (1992). 16. Onderzoek naar toepassingen is op het gebied van interne Berichtgeving heel wat moeilijker dan op het gebied van externe Berichtgeving. Keuzes van ondernemingen zijn maar moeilijk waarneembaar. Dit soort onderzoek is dus moeilijker. Vgl. voor empirisch economisch onderzoek van dit moeilijke type, een aantal bijdragen in de fascinerende bundel Temin (1991).

17. Een goed overzicht van bestaande technieken is bijvoorbeeld te vinden in Arens en Loebbecke (1991). Vgl. voor een overzicht van onderzoek op het terrein van accountantscontrole ook Ted Mock's Maastrichtse oratie (Mock (1992)).

18. Dezelfde vraag, maar dan gericht op de rol van banken en andere financiële tussenpersonen in een economie, wordt gesteld en behandeld door Hellwig (1991) in een fascinerend essay.

19. Er is over deze vraag al een wat oudere literatuur. Daarin is de vraag of de techniek van het dubbel-boekhouden iets te maken heeft met de opkomst van het kapitalisme. Yamey (1964) is daar sceptisch over. Maar zijn scepsis richt zich op de specifieke rol van dubbel-boekhouden, niet op de rol van Berichtgeving in het algemeen.

20. Voor een kort portret van Romer en zijn collega's, vgl. Farrell (1994).

21. Een eerdere gelijkaardige empirische analyse is te vinden in hoofdstuk 8 van Magee, Brock en Young (1989). $\mathrm{Zij}$ concluderen: "The more lawyers per doctor, the lower the country's per capita growth rate.".

22. In hetgeen volgt beperk ik me tot de empirisch meest succesvolle economische onderzoeksrichting op het terrein van externe Berichtgeving, de contractkosten of agentschap theorie en de verdere ontwikkelingen daarin. Vgl. Whittred en Zimmer (1992, hfdstk. 2) voor een beschrijving van signaalgeving theorie als een andere potentieel vruchtbare theorie op dit terrein. Healy en Palepu (1993) is daarvan een voorbeeld. Vgl. ook de beschouwing over een economische theorie van externe Berichtgeving door Holthausen (1990). Overigens is Whittred en Zimmer (1992) het eerste handboek dat een gedetailleerde behandeling van technieken van externe Berichtgeving koppelt aan de nieuwe theorie en empirie op dit gebied.

23. De Bondt (1993) en Milgrom en Roberts (1992) geven een beschrijving van de nieuwe theorie van de onderneming.

24. Het empirische onderzoek dat Watts en Zimmerman (1986) samenvat is allemaal in de vorm van retrodicties, d.w.z. het is geen echt voorspellend onderzoek (geen predicties). Vgl, voor een bijzonder heldere beschrijving van predictie en retrodictie om een theorie empirisch te toetsen, Weinberg (1993, pp.71-84). Voor een bundeling van veel van de oorspronkelijke studies op dit terrein met informatieve introducties, vgl. Ball en Smith (1993). Christie (1990) is een 'metaanalyse' van individuele studies, met als conclusie dat agentschapstheorie inderdaad verklarende kracht heeft op het terrein van externe Berichtgeving. 
25. Vgl. voor een heel recente bundeling van empirische studies op dit terrein Ball en Kothari (1994).

26. Dit zou, in de Nederlandse situatie, wel kunnen gehinderd worden door de bestaande machtsverhoudingen tussen management en met name aandeelhouders. Door beschermingsconstructies en door het Structuurregime vallen die in het voordeel uit van het management. Afbouw van deze scheefheid is ook om de hier geschetste redenen belangrijk. (vgl. ook, Boot (1993, sectie 3)).

27. Vgl. Romer (1993) voor een institutioneel ontwerp op het terrein van het bevorderen van de ontwikkeling van fysieke technologie door de overheid, dat ook probeert concurrentie in het proces te introduceren.

28. De eerste Nederlandstalige gedrukte handleiding verscheen in 1543 in Antwerpen van de hand van Jan Ympyn. Ympyn's boek is, in het Engels vertaald, invloedrijk geweest in het Verenigd Koninkrijk. De grote Vlaamse historicus van administratieve technologie Raymond de Roover schreef een interessant artikel over Ympyn (De Roover (1937)). Terugkijkend op mijn Antwerpse economie studie is het in dit verband verbazingwekkend dat tijdens die studie noch Ympyn, noch De Roover ter sprake kwamen.

29. Vgl. hierover de volgende opmerking van Demski (1985,p.71): "It is not terribly surprising that we regard bonding, non-financial measures, customer statistics and supervision as substitutes for accounting measures. What is surprising, and profound, is that we also regard reputation, equity price, intrafirm tournaments, repetition, industry comparison, self reports, promotion hierarchies and incentive payments as potential substitutes for accounting measures.".

30. Elegant ook in deze zin, dat ze overdraagbaar zijn tussen specialismen binnen de Bedrijfseconomie. Agentschap theorie is dat. Vgl. bijvoorbeeld Thakor (1993), voor een overzicht van recente toepassingen ervan op investeringsbeslissingen door ondernemingen.

31. Ik dank Steven Maijoor en Tom Groot voor hun waardevolle commentaar bij een eerdere versie van deze rede. 


\section{Literatuur}

Alexander,D., C.Nobes, (1994), A European introduction to financial accounting, Prentice Hall International, Hemel Hempstead.

Anderson,D., J.Francis, D.Stokes, (1993), Auditing, directorships and the demand for monitoring, in: Journal of Accounting and Public Policy, 12 , pp.353-375.

Arens,A., J.Loebbecke, (1991), Auditing: an integrated approach, Prentice Hall, Englewood Cliffs.

Barten, A., (1989), Econometrische lessen, Academic Service, Schoonhoven.

Ball,R., (1989), The firm as a specialist contracting intermediary: application to accounting and auditing, working paper, University of Rochester, Rochester.

Ball,R., C.Smith, (eds.), (1992), The economics of accounting policy choice, McGraw-Hill, New York.

Ball,R., S.Kothari, (eds.), (1994), Financial statement analysis, McGraw-Hill, New York.

Baumol,W., (1986), Productivity growth, convergence and welfare: what the long-run data show, in: American Economic Review, 76, pp.1072-1085.

Benson,B., (1989), The spontaneous evolution of commercial law, in: Southern Economic Journal, 55, pp.644-661.

Bindenga, A., (1991), Een toekomst voor de Nederlandse accountancy, oratie, Erasmus Universiteit, Rotterdam.

Black,F., M.Scholes, (1973), The pricing of options and corporate liabilities, in: Journal of Political Economy, 81, pp.637-659.

Black,F., (1989), How we came up with the option formula, in: Journal of Portfolio Management, 15, pp.4-8.

Black,F., (1993), Choosing accounting rules, in: Accounting Horizons, 7, pp.117.

Bougen,P., (1993), Joking apart: the serious side to the accountant stereotype, in: Accounting, Organizations and Society, 19, pp.319-335.

Bouma,J., (1967), De toepassing van intern-gedragsmodellen in de bedrijfseconomie, oratie, FdEW, Rijksuniversiteit Groningen.

Boot,A., (1993), De financiering van het bedrijfsleven: tussen structuurregime en financiële sector, oratie, FEWEC, UvA, Amsterdam.

Brink,H., (1991), ... en ook overigens in overeenstemming met de wettelijke bepalingen inzake de jaarrekening, in: De Accountant, september, pp.29.

Cheung,J., (1993), Managerial flexibility in capital investment decisions: insights from the real-options literature, in: Journal of Accounting Literature, 12, pp.29-66. 
Christie,A., (1990), Aggegation of test statistics, in: Journal of Accounting and Economics, 12, pp.15-36.

Coase,R., (1990), Accounting and the theory of the firm, in: Journal of Accounting and Economics, 12, pp.3-13.

Coase,R., (1937), The nature of the firm, in: Economica, 9, pp.386-405.

Cooper,R., R.Kaplan, (1992), Activity-based systems: measuring the costs of resource usage, in: Accounting Horizons, 6, pp.1-13.

De Bondt,R., (1993), Fundamentele bedrijfseconomie, Wolters, Leuven.

De Long,B., (1988), Productivity growth, convergence and welfare: comment, in: American Economic Review, 78, pp.1138-1154.

Demski,J, (1985), Accounting research: 1985, in: Contemporary Accounting Research, 2, pp.69-75.

De Roover,R., (1937), Eén en ander over Jan Ympyn Christoffels, Tijdschrift voor Geschiedenis, 52, pp.63-179.

Dixit,A., R.Pindyck, (1994), Investment under uncertainty, Princeton University Press, Princeton.

Edwards,J., (1991), The process of accounting innovation: the publication of consolidated accounts in Britain in 1910, in: Accounting Historians Journal, 18, pp.113-132.

Easterbrook,F., D.Fischel, (1984), Mandatory disclosure and the protection of investors, in: Virginia Law Journal, 70, pp.669-715.

Farrell,C., (1994), America's new growth economy, in: Business Week, May 16, pp.42-48.

Faulhaber,G., W.Baumol, (1988), Economists as innovators: practical products of theoretical research, in: Journal of Economic Literature, 26, pp.577600.

Gal-Or,E., (1993), Strategic cost allocation, in: Journal of Industrial Economics, 41, pp.387-402.

Hamada, R., et.al., (1988), The role of statistics in accounting, marketing, finance and production, in: Journal of Business and Economic Statistics, 6, pp.261-272.

Healy,P., K.Palepu, (1993), The effect of firms' financial disclosure strategies on stock prices, in: Accounting Horizons, 7, pp.1-11.

Hellwig,M., Banking, financial intermediation and corporate finance, in: A.Giovanni, C.Mayer, (eds), (1991), European financial integration, Cambridge University Press, Cambridge, pp.35-63.

Holthausen,R., (1990), Accounting method choice: opportunistic behavior, efficient contracting and information perspectives, in: Journal of Accounting and Economics, 12, pp.207-218.

Hoogendoorn,M., (1993), Botsende beginselen in de externe verslaggeving, oratie, UvA, Amsterdam. 
King,R., R.Levine, (1993), Finance and growth: Schumpeter might be right, in: Quarterly Journal of Economics, 108, pp.717-737.

Klaassen,J., G.Zevenboom, (1993), De nieuwe jaarverslaggeving, FED/KPMG, Deventer.

Kuijl,H., (1990), Geven en nemen: fiscale aspecten van de wetgeving op de jaarrekening in historisch perspectief, oratie, Rijksuniversiteit Leiden, Leiden.

Lucas,R., (1988), On the mechanics of economic development, in: Journal of Monetary Economics, 22, pp.3-42.

Maijoor,S., (1991), The economics of accounting regulation, Datawyse, Maastricht.

Mezias, S., (1990), An institutional model of organizational practice: financial reporting at the Fortune 200, in: Administrative Science Quarterly, 35, pp.431-457.

Milgrom,P., J.Roberts, (1992), Economics, organization and management, Prentice Hall, Englewood Cliffs.

Mock,T., (1992), Auditing research: evolution, traditions and prospects, oratie, FdEW, Rijksuniversiteit Limburg.

Morse,D., (1993), Explaining the international supply of auditors, in: International Journal of Accounting, 28, pp.347-355.

Murphy,K., A.Shleifer, R.Vishny, (1991), The allocation of talent: implications for growth, in: Quarterly Journal of Economics, 106, pp.501-530.

Noreen,E., (1987), Commentary on 'Relevance lost', in: Accounting Horizons, 2, pp.110-116.

Penman,S., (1991), Return to fundamentals, paper presented to the 1991 annual conference of the AAANZ, working paper.

Penman,S., (1992), Return to fundamentals, in: Journal of Accounting Auditing and Finance, 7 , pp.465-483.

Quadackers,L, T.Mock, S.Maijoor, (1994), Audit risk and audit programs: some archival evidence from four large Dutch audit firms, paper presented at the EAA annnual conference, Venice, April.

RJ (Raad voor de Jaarverslaggeving), (s.d.), Richtlijnen voor de Jaarverslaggeving na 1990 , losbladig, Kluwer, Deventer.

Romer,P., (1993), Idea gaps and object gaps in economic development, in: Journal of Monetary Economics, 32, pp.543-573.

Romer,P., (1993), Implementing a national technology strategy with selforganising industry investment boards, in: Brooking papers on Economic Activity, Microeconomics issue, pp.345-390.

Romer,P., (1994), The origins of endogenous growth, in: Journal of Economic Perspectives, 8, pp.3-22.

Scholes,M., M.Wolfson, (1992), Taxes and business strategy: a planning approach, Prentice Hall, Englewood Cliffs. 
Schreuder,H., (1985), Accounting research and practice, in: A.Rinnooy Kan, New challenges for management research, Elsevier, Amsterdam.

Simon,H., (1981), The sciences of the artificial, MIT Press, Boston

Skinner,D., (1993), The investment opportunity set and accounting procedure choice: preliminary evidence, in: Journal of Accounting and Economics, 16, pp.407-445.

Soete,L., (1987), Technologie en economie, oratie, FdEW, Rijksuniversiteit Limburg, Maastricht.

Temin,P.,(ed), (1991), Inside the business enterprise: historical perspectives on the use of information, University of Chicago Press, Chicago.

Thakor,A., (1993), Corporate investments and finance, in: Financial Management, pp.135-144.

Van Hulle,K., (1993), Harmonization of accounting standards in the EC: is it the beginning or is it the end ?, in: European Accounting Review, 2, pp.387-396.

Van Witteloostuijn,A., (1994), Laat duizend bloemen bloeien, oratie, FdEW, Rijksuniversiteit Limburg, Maastricht.

Van de Poel,J., F.Tempelaar, On the applicability of positive agency theory, RM87-019, RL, FdEW, Maastricht.

Van de Poel,J., (1988), Als de tekenen bedriegen ..., oratie, FdEW, Rijksuniversiteit Limburg, Maastricht.

Waldrop,M., (1992), Complexity: the emerging science at the edge of order and chaos, Viking, New York/London.

Watts,R., (1977), Corporate financial statements: a product of the market and political processes, in: Australian Journal of Management, 2, pp.53-75.

Watts,R., J.Zimmerman, (1983), Agency problems, auditing and the theory of the firm, in: Journal of Law and Economics, 26, pp.613-634.

Watts,R., J.Zimmerman, (1986), Positive accounting theory, Prentice Hall, Englewood Cliffs.

Watts,R., J.Zimmerman, (1990), Positive accounting theory: a ten year perspective, in: Accounting Review, 65, pp.131-156.

Weinberg,S., (1993), Dreams of a final theory, Vintage, London.

Whittington,G., (1992), The elements of accounting: an introduction, CUP, Cambridge.

Whittred,G., I.Zimmer, (1992), Financial accounting: incentive effects and economic consequences, Holt Rhinehart Winston, Sidney.

Wilson,G.P., (1994), Leveraging our core competencies: structuring and communicating knowledge, in: Accounting Education News, May, pp. 18,20 .

Wilson,R., (1983), Auditing: perspectives from multi-person decision theory, in: Accounting Review, 58, pp.305-318. 
Wolfson, M., (1993), The effects of ownership and control on tax and financial reporting policy, in: Economic Notes by Monte dei Paschi di Siena, 22, pp.318-332.

Yamey,B., (1964), Accounting and the rise of capitalism, in: Journal of Accounting Research, 2, pp.117-136.

Zeff,S., F.van der Wel, K.Camfferman, (1992), Company financial reporting: a historical and comparative study of the dutch regulatory process, North Holland, Amsterdam.

Zeff,S., B.Dharan, (eds.), (1994), Readings and notes on financial accounting, McGraw-Hill, New York. 